УДК 636.13:57.08:575.116.4

(C) 2013

Ткачова О. Л., молодший науковий співробітник, Добродєєва Л. Т., науковий співробітник,

Россоха Л. В., Россоха В. І., Ткачов О. В., кандидати сільськогосподарських наук Інститут тваринництва НААН України

\title{
ЦИТОГЕНЕТИЧНА ТА БІОТЕХНОЛОГІЧНА ОЦІНКА ЖЕРЕБЦІВ ТРАКЕНЕНСЬКОЇ ТА ГАННОВЕРСЬКОЇ ПОРІД
}

\section{Рецензент - кандидат сільськогосподарських наук Н. О. Косов}

Проведено порівняльну циитогенетичну $і$ біотехнологічну оиінку обстежених жеребиів тракененської та ганноверської порід за загальною хромосомною нестабільністю й кількісними та якісними показниками сперми після відтавання. За загальної хромосомної нестабільності обстежених жеребиів ганноверської породи 4,9\% біотехнологічна придатність сперми становила 76,19\%, у жеребиів тракененської породи біотехнологічна придатність сперми становила 72,73\% за хромосомної нестабільності 5,91\%. На біотехнологічну придатність сперми обстежених жеребиів впливає також наявність парних і кольцевих аберацій.

Ключові слова: жеребець, сперма, ичитогенетика, біотехнологія, селекиія.

Постановка проблеми. Необхідність застосування генетичного, зокрема цитогенетичного тестування в Україні регламентується Законом України «Про племінну справу у тваринництві» $\mathrm{i}$ «Положенням про порядок генетичної експертизи походження і виявлення аномалій племінних тварин». Відповідно до цих законодавчих актів генетичному тестуванню мають підлягати всі племінні тварини: коні, велика рогата худоба, свині, кролі, птиця й навіть риба [1]. В зв'язку 3 цим для підвищення показників відтворення коней слід надавати особливої уваги цитогенетичним та біотехнологічним дослідженням жеребців-плідників, оскільки у разі використання їх сперми у системі штучного осіменіння кобил у рази збільшуються ризики розповсюдження хромосомних аномалій, що можуть завдати чималих економічних збитків галузі.

Аналіз основних досліджень і публікацій, у яких започатковано розв'язання проблеми. Селекція в конярстві тривалий час спиралася на дослідження показників якості сперми та результати іiі застосування в штучному осіменінні [5]. Тривалий час вона проводилася без цитогенетичних досліджень, що призвело до накопичення хромосомних дефектів у популяціях і знизило репродуктивну функцію жеребців-плідників та конематок, а врешті-решт - і вихід лошат до критичного рівня [2]. Розвиток досліджень хромосом сільськогосподарських тварин $[2,3]$ та усвідомлення ролі цитогенетики у розв'язанні селекційних проблем тваринництва [1] дали можливість упровадити цитогенетичні методи й у конярство.

Мета і завдання досліджень. Метою даної роботи $\epsilon$ проведення цитогенетичної і біотехнологічної оцінки жеребців-плідників тракененської та ганноверської порід за загальною хромосомною нестабільністю й кількісними та якісними показниками сперми після відтавання.

Завданнями досліджень було: 1) провести оцінку якості відталої сперми жеребців-плідників ганноверської та тракененської порід; 2) провести цитогенетичну оцінку обстежених жеребців за структурними абераціями хромосом.

Методика проведення досліджень. Дослідження проводили на трьох плідниках ганноверської породи і на одному жеребцеві тракененської породи Харківського кінного заводу Харківської області та на трьох жеребцях тракененської породи Чутівського кінного заводу «Тракен» Полтавської області. Отримання й кріоконсервацію сперми жеребців проводили за харківською технологією, що розроблена відділом біотехнології репродукції тварин IT НААН [3]. Виготовлення препаратів хромосом коней проводили згідно із загальноприйнятими методиками [4]. У ході аналізу препаратів хромосом від кожного плідника враховували загальну хромосомну нестабільність; загальну кількість аберацій; кількість аберацій у перерахунку на сто клітин; абсолютну й відносну кількість одиничних, парних i кільцевих аберацій [5]. Статистичне опрацювання результатів здійснювали за загальноприйнятими методиками [6].

Результати досліджень. Проведено оцінку якості деконсервованої сперми ганноверських i тракененських жеребців (табл. 1).

Серед жеребців ганноверської породи найкраща біотехнологічна придатність сперми була 
у Сандроз-Діаманта, що простежується за найбільшим відсотком кріорезистентних еякулятів, (це на 14,29 \% більше за Монакко та на 57,14 \% більше за Маркузі). Найбільша рухливість сперміїв після деконсервації була у СандрозДіаманта та Маркузі, що на 1,17 балу більше $(\mathrm{p}<0,01)$ за Монакко. Найбільша виживаність сперміїв була у Сандроз-Діаманта, що на 0,85 години більше за Монакко та на 1,6 години $(p<0,05)$ - за Маркузі. Найбільша збереженність сперміїв була у Монакко - на 1,3 \% більше від Сандроз-Діаманта і на 8,49 \% - за Маркузі.

3-поміж плідників тракененської породи найбільший відсоток біотехнологічної придатності еякулятів було встановлено у Трона, що на $5,71 \%$ більше за Арлеана, на 25,71\% більше за Пеона та Проспекта. Найбільша рухливість відталої сперми була у Трона, що на 0,97 балу більше за Пеона, на 0,77 балу - за Арлеана й на 0,67 балу більше за Проспекта. Виживаність сперміїв найбільша у Трона, що на 0,44 години більше за Пеона, на 0,84 години більше за Арлеана та Проспекта. Збереженність сперміїв була найбільшою у Трона: це на 18,95\% більше за Пеона, на 14,67 \% - за Арлеана та на 13,99 \% більше за збереженність сперміїв Проспекта.

Наступний етап дослідження - проведення цитогенетичної оцінки обстежених жеребців за структурними абераціями хромосом. Показники цитогенетичного обстеження за структурними абераціями хромосом жеребців-плідників ганноверської та тракененської порід наведено у таблиці 2.

3 даних таблиці 2 видно, що найбільша кількість метафаз із абераціями була у Маркузі й Проспекта, що на одну метафазу більше за Арлеана, на 0,5 метафази більше за Пеона і Трона, на 2 метафази більше $(\mathrm{p}<0,05)$ за СандрозДіаманта й Монакко. Допустимий рівень загальної хромосомної нестабільності демонстрували плідники Сандроз-Діамант і Монакко. Підвищений рівень загальної хромосомної нестабільності мали плідники Маркузі - на 2,05 \% більше допустимого рівня, Трон - на 1,5\%, Пеон - на $0,9 \%$, Арлеан - на 0,5 \% і Проспект - на 0,75\%.

Загальна кількість аберацій найменшою була у Сандроз-Діаманта, що на одну аберацію менше за Монакко, на 5 аберацій менше $(\mathrm{p}<0,05)$ за Маркузі та Арлеана, на 2 аберації менше за Трона, на 4,5 аберації менше $(\mathrm{p}<0,05)$ за Пеона, на 4,5 аберації менше $(\mathrm{p}<0,05)$ за Проспекта. У перерахунку на 100 клітин найменше аберацій було у Сандроз-Діаманта, що на 1,95 аберацію менше $(\mathrm{p}<0,05)$ за Монакко, на 8,45 аберацій менше за Маркузі, на 3,7 - за Трона, на 7,55 - за Пеона, на 8,85 - за Арлеана $(\mathrm{p}<0,01)$ та на 5,5 аберацій більше $(\mathrm{p}<0,05)$ за Проспекта.

Кількість одиничних аберацій серед плідників ганноверської та тракененської порід знаходилася приблизно на одному рівні. Відсоток одиничних аберацій найбільшим був у Сандроз-Діаманта, що на 33,3 \% більше за Монакко, на 85,4 \% - за Маркузі (p<0,001), на 53,35 \% - за Трона, на 61,9 \% - за Пеона (p<0,01), на 70,85 \% - за Арлеана $(\mathrm{p}<0,01)$ i на $61,9 \%$ більше $(\mathrm{p}<0,01)$ за Проспекта.

Кількість парних аберацій серед плідників ганноверської та тракененської порід була не більше двох; лише у Сандроз-Діаманта не було встановлено їх наявність. Найбільший відсоток парних аберацій було у Монакко, що на 16,65 \% більше за Маркузі, на 6,65 \% - за Трона, на 3,5 \% - за Пеона, на $12,45 \%$ - за Арлеана та на 2,35 \% більше за Проспекта.

\section{1. Показники відталої сперми жеребців-плідників ганноверської та тракененської порід}

\begin{tabular}{|c|c|c|c|c|c|c|}
\hline \multirow[b]{2}{*}{ Плідник } & \multirow[b]{2}{*}{$\begin{array}{l}\text { Кількість, } \\
\text { еякулятів }\end{array}$} & \multirow{2}{*}{$\begin{array}{c}\text { Кількість } \\
\text { еякулятів, } \\
\text { що заморо- } \\
\text { жували }\end{array}$} & \multirow[b]{2}{*}{$\begin{array}{c}\text { Кріорезис- } \\
\text { тентність, } \\
\%\end{array}$} & \multicolumn{3}{|c|}{ Показники відталої сперми $(\mathrm{M} \pm \mathrm{m})$} \\
\hline & & & & $\begin{array}{c}\text { рухливість } \\
\text { сперміїв, бали }\end{array}$ & $\begin{array}{c}\text { виживаність } \\
\text { сперміїв за } 37^{\circ} \mathrm{C}, \\
\text { годин }\end{array}$ & $\begin{array}{c}\text { збереженість } \\
\text { сперміїв, \% }\end{array}$ \\
\hline \multicolumn{7}{|c|}{ Ганноверська порода } \\
\hline $\begin{array}{l}\text { Сандроз- } \\
\text { Діамант }\end{array}$ & 7 & 7 & 100,00 & $3,50 \pm 0,22$ & $4,10 \pm 0,33$ & $53,86 \pm 1,62$ \\
\hline Монакко & 7 & 6 & 85,71 & $3,50 \pm 0,16$ & $3,25 \pm 0,28$ & $55,16 \pm 1,74$ \\
\hline Маркузі & 7 & 3 & 4 & $2,33 \pm 0,17 * *$ & $2,50 \pm 0,29^{*}$ & $46,67 \pm 3,33$ \\
\hline Усього & 21 & 16 & 76,19 & $3,23 \pm 0,18$ & $3,39 \pm 0,24$ & $52,70 \pm 1,45$ \\
\hline \multicolumn{7}{|c|}{ Тракененська порода } \\
\hline Трон & 7 & 6 & 85,71 & $3,17 \pm 0,19$ & $2,94 \pm 0,10$ & $58,33 \pm 3,38$ \\
\hline Пеон & 5 & 3 & 60,00 & $2,20 \pm 0,34$ & $2,50 \pm 0,39$ & $39,38 \pm 6,88$ \\
\hline Арлеан & 5 & 4 & 80,00 & $2,40 \pm 0,51$ & $2,10 \pm 0,46$ & $43,66 \pm 8,57$ \\
\hline Проспект & 5 & 3 & 60,00 & $2,50 \pm 0,27$ & $2,10 \pm 0,43$ & $44,34 \pm 3,51$ \\
\hline Усbого & 22 & 16 & 72,73 & $2,67 \pm 0,17$ & $2,50 \pm 0,16$ & $48,41 \pm 3,00$ \\
\hline
\end{tabular}

Примітка: ${ }^{*}-\mathrm{p}<0,05, * *-\mathrm{p}<0,01$ 
СІЛЬСЬКЕ ГОСПОДАРСТВО. ТВАРИННИЦТВО

\section{2. Структурні аберації хромосом жеребців-плідників ганноверської та тракененської порід} $(M \pm m)$

\begin{tabular}{|c|c|c|c|c|c|c|c|c|c|c|c|}
\hline \multirow{3}{*}{ Плідник } & \multirow{3}{*}{$\begin{array}{c}\text { Кіль- } \\
\text { кість } \\
\text { мета- } \\
\text { фа3 }\end{array}$} & \multirow{2}{*}{\multicolumn{2}{|c|}{$\begin{array}{c}\text { Метафаз } \\
\text { iз абераціями }\end{array}$}} & \multicolumn{8}{|c|}{ Аберації } \\
\hline & & & & \multirow{2}{*}{ усього } & \multirow{2}{*}{$\begin{array}{l}\text { на } 100 \\
\text { клітин }\end{array}$} & \multicolumn{2}{|c|}{ одиничні } & \multicolumn{2}{|c|}{ парні } & \multicolumn{2}{|c|}{ кільцеві } \\
\hline & & $n$ & $\%$ & & & $n$ & $\%$ & $n$ & $\%$ & $n$ & $\%$ \\
\hline \multicolumn{12}{|c|}{ Ганноверська порода } \\
\hline $\begin{array}{l}\text { Сандро3- } \\
\text { Діамант }\end{array}$ & 105 & $\begin{array}{c}2,00 \\
\pm 0,00 \\
\end{array}$ & $\begin{array}{c}3,82 \\
\pm 0,18 \\
\end{array}$ & $\begin{array}{c}2,00 \\
\pm 0,00 \\
\end{array}$ & $\begin{array}{c}3,80 \\
\pm 0,20\end{array}$ & $\begin{array}{c}2,00 \\
\pm 0,00 \\
\end{array}$ & $\begin{array}{l}100,0 \\
\pm 0,00\end{array}$ & $\begin{array}{c}0,00 \\
\pm 0,00 \\
\end{array}$ & $\begin{array}{c}0,00 \\
\pm 0,00 \\
\end{array}$ & \begin{tabular}{|c|}
0,00 \\
$\pm 0,00$ \\
\end{tabular} & \begin{tabular}{|c|}
0,00 \\
$\pm 0,00$ \\
\end{tabular} \\
\hline Монакко & 105 & $\begin{array}{c}2,00 \\
\pm 0,00\end{array}$ & $\begin{array}{c}3,82 \\
\pm 0,18 \\
\end{array}$ & $\begin{array}{c}3,00 \\
\pm 0,00\end{array}$ & $\begin{array}{c}5,75 \\
\pm 0,25^{*}\end{array}$ & $\begin{array}{c}2,00 \\
\pm 0,00\end{array}$ & $\begin{array}{l}66,70 \\
\pm 0,00\end{array}$ & $\begin{array}{c}1,00 \\
\pm 0,00 \\
\end{array}$ & $\begin{array}{l}33,30 \\
\pm 0,00 \\
\end{array}$ & \begin{tabular}{|c|}
0,00 \\
$\pm 0,00$ \\
\end{tabular} & \begin{tabular}{|c|}
0,00 \\
$\pm 0,00$ \\
\end{tabular} \\
\hline Маркузі & 115 & $\begin{array}{c}4,00 \\
\pm 1,00\end{array}$ & $\begin{array}{c}7,05 \\
\pm 2,05\end{array}$ & $\begin{array}{c}7,00 \\
\pm 1,00^{*}\end{array}$ & & $\begin{array}{c}1,00 \\
\pm 0,00\end{array}$ & $\begin{array}{c}14,60 \\
\pm 2,10 * * *\end{array}$ & $\begin{array}{c}1,00 \\
\pm 1,41\end{array}$ & $\begin{array}{l}16,65 \\
\pm 23,6\end{array}$ & $\begin{array}{c}5,00 \\
\pm 2,00\end{array}$ & $\begin{array}{l}68,75 \\
\pm 18,8\end{array}$ \\
\hline Усього & 325 & $\begin{array}{c}2,67 \\
\pm 0,49\end{array}$ & $\begin{array}{c}4,90 \\
\pm 0,86\end{array}$ & $\begin{array}{c}4,00 \\
\pm 1,00\end{array}$ & $\begin{array}{c}7,27 \\
\pm 1,72\end{array}$ & $\begin{array}{c}1,67 \\
\pm 0,21\end{array}$ & $\begin{array}{c}60,43 \\
\pm 15,73\end{array}$ & $\begin{array}{c}0,67 \\
\pm 0,47\end{array}$ & $\begin{array}{c}16,65 \\
\pm 10,53\end{array}$ & $\begin{array}{c}1,67 \\
\pm 2,03\end{array}$ & $\begin{array}{c}22,92 \\
\pm 26,47\end{array}$ \\
\hline \multicolumn{12}{|c|}{ Тракененська порода } \\
\hline Трон & 110 & $\begin{array}{c}3,50 \\
\pm 0,50 \\
\end{array}$ & $\begin{array}{c}6,50 \\
\pm 1,50 \\
\end{array}$ & $\begin{array}{c}4,00 \\
\pm 1,00 \\
\end{array}$ & $\begin{array}{r}7,50 \\
\pm 2,50\end{array}$ & $\begin{array}{c}2,00 \\
\pm 1,00 \\
\end{array}$ & $\begin{array}{l}46,65 \\
\pm 13,4 \\
\end{array}$ & $\begin{array}{c}1,00 \\
\pm 0,00 \\
\end{array}$ & $\begin{array}{l}26,65 \\
\pm 6,65 \\
\end{array}$ & \begin{tabular}{|c|}
1,00 \\
$\pm 0,00$ \\
\end{tabular} & \begin{tabular}{|l|}
26,65 \\
$\pm 6,65$ \\
\end{tabular} \\
\hline Пеон & 119 & $\begin{array}{c}3,50 \\
\pm 0,50 \\
\end{array}$ & $\begin{array}{c}5,90 \\
\pm 0,10 * *\end{array}$ & $\begin{array}{c}6,50 \\
\pm 0,50 * \\
\end{array}$ & $\begin{array}{l}11,35 \\
\pm 2,65 \\
\end{array}$ & $\begin{array}{c}2,50 \\
\pm 0,50 \\
\end{array}$ & \begin{tabular}{|c|}
38,10 \\
$\pm 4,80 * *$ \\
\end{tabular} & $\begin{array}{c}2,00 \\
\pm 1,00 \\
\end{array}$ & $\begin{array}{r}29,80 \\
\pm 13,1 \\
\end{array}$ & \begin{tabular}{|c|}
2,00 \\
$\pm 1,00$ \\
\end{tabular} & \begin{tabular}{|l|}
32,15 \\
$\pm 17,9$ \\
\end{tabular} \\
\hline Арлеан & 110 & $\begin{array}{c}3,00 \\
\pm 0,00 \\
\end{array}$ & $\begin{array}{c}5,50 \\
\pm 0,50 \\
\end{array}$ & $\begin{array}{c}7,00 \\
\pm 1,00^{*} \\
\end{array}$ & $\begin{array}{c}12,65 \\
\pm 0,65 * * \\
\end{array}$ & $\begin{array}{c}2,00 \\
\pm 0,00 \\
\end{array}$ & $\begin{array}{c}29,15 \\
\pm 4,15 * * \\
\end{array}$ & $\begin{array}{r}1,50 \\
\pm 0,50 \\
\end{array}$ & $\begin{array}{l}20,85 \\
\pm 4,15 \\
\end{array}$ & $\begin{array}{c}3,50 \\
\pm 0,50 \\
\end{array}$ & $\begin{array}{l}50,00 \\
\pm 0,00 \\
\end{array}$ \\
\hline $\begin{array}{l}\text { Про- } \\
\text { спект }\end{array}$ & 140 & $\begin{array}{c}4,00 \\
\pm 0,00^{*}\end{array}$ & $\begin{array}{c}5,75 \\
\pm 0,25^{*} \\
\end{array}$ & $\begin{array}{c}6,50 \\
\pm 0,50 *\end{array}$ & $\begin{array}{c}9,30 \\
\pm 1,10^{*}\end{array}$ & $\begin{array}{c}2,50 \\
\pm 0,50 \\
\end{array}$ & $\begin{array}{c}38,10 \\
\pm 4,80 * *\end{array}$ & $\begin{array}{l}2,00 \\
\pm 0,00\end{array}$ & $\begin{array}{l}30,95 \\
\pm 2,35\end{array}$ & $\begin{array}{c}2,00 \\
\pm 0,00\end{array}$ & $\begin{array}{l}30,95 \\
\pm 2,35 \\
\end{array}$ \\
\hline 020 & 479 & $\begin{array}{c}3,50 \\
\pm 0,19 \\
\end{array}$ & $\begin{array}{c}5,91 \\
\pm 0,33 \\
\end{array}$ & $\begin{array}{c}6,00 \\
\pm 0,53 \\
\end{array}$ & $\begin{array}{l}10,20 \\
\pm 1,04 \\
\end{array}$ & $\begin{array}{c}2,25 \\
\pm 0,25 \\
\end{array}$ & $\begin{array}{r}38,00 \\
\pm 3,75 \\
\end{array}$ & $\begin{array}{c}1,63 \\
\pm 0,26 \\
\end{array}$ & $\begin{array}{l}27,06 \\
\pm 3,27 \\
\end{array}$ & $\begin{array}{cc}2,13 \\
\pm 0,40 \\
\end{array}$ & $\begin{array}{l}34,94 \\
\pm 4,96 \\
\end{array}$ \\
\hline
\end{tabular}

Примітка: ${ }^{*}-p<0,05 ; * *-p<0,01 ; * * *-p<0,001$

Кільцевих аберацій не було встановлено у Сандроз-Діаманта та Монакко. Найбільша кількість кільцевих аберацій була у Маркузі, що на 4 аберації більше за Трона, на 3 аберації - за Пеона та Проспекта та на 1,5 аберації більше за Арлеана. Найбільший відсоток кільцевих аберацій було встановлено у Маркузі, що на 42,1 \% більше за Трона, на 36,6 \% - за Пеона, на 37,8 \% - за Проспекта та на $18,75 \%$ більше за Арлеана.

Висновки: 1. Встановлено, що обстежені жеребці ганноверської породи за середнього допусти-

\section{БІБЛІОГРАФІЯ}

1. Буркат В. П. Цитогенетика у розв'язанні селекційних проблем тваринництва / Буркат В. П., Дзіцюк В. В. - Вісник аграрної науки. - №1, 2004. - C. 37-39.

2. Графодатский А. С. Хромосомы сельскохозяйственных и лабораторных млекопитающих / Графодатский А. С., Раджабли С. И. - Новосибирск, 1988. $-128 \mathrm{c}$.

3. Исследование хромосом сельскохозяйственных животных / Методические рекомендации / Под ред. А. Ф. Яковлева. - Ленинград, 1976. - 65 с.

4. Плохинский Н. А. Руководство по биометрии для зоотехников / Н. А. Плохинский. - М. : Ко- мого рівня загальної хромосомної нестабільності у 4,9\% мали середню біотехнологічну придатність сперми 76,19\%. Жеребці тракененської породи 3 підвищеним середнім рівнем загальної хромосомної нестабільності 5,91 \% демонстрували біотехнологічну придатність сперми на рівні $72,73 \%$.

2. Доведено, що в обстежених жеребців ганноверської породи відносна кількість одиничних аберацій була більше на 22,43 \%, парних аберацій було менше на 10,41 \%, а кольцевих аберацій було менше на 11,82 \% за тракененських плідників.

лос, $1969 .-256$ с.

5. Розробка технологічної лінії для отримання, кріоконсервації сперми жеребців та штучного осіменіння кобил / О. Б. Сушко, О. О. Новіков, Ф. І. Осташко [та ін.] / Матеріали Міжнародної науково-практичної конференції «Тваринництво XXI сторіччя: новітні технології, досягнення i перспективи» // НТБ ІТ УААН. - №94. - Х., 2006. - C. 325-330.

6. Ткачова I. В. Стратегія розвитку галузі конярства в Україні / I. В. Ткачова // НТБ ІТ НААН. №103. - X., 2010. - C. 8-16. 